Litinfinite Journal

ISSN: 2582-0400 [Online]

CODEN: LITIBR

Vol-2, Issue-1 ( $2^{\text {nd }}$ July, 2020)

Page No: 39-43

DOI: 10.47365/litinfinite.2.1.2020.39-43

Section: Article

\title{
Reading a Textual Analysis and Nature in "Full Moon and Little Frieda" by Ted Hughes
}

\author{
Shamaila Amir \\ Hamdard Institute of Education and Social Sciences, \\ Hamdard University, Karachi 74600, Pakistan \\ Mil I.d.:shaminhasan@hotmail.com
}

\begin{abstract}
:
The description and textual interpretation of the characteristics of a text highlights and takes into account how it is written in the form of a visual message. What any form of textual analysis conveys is that, it throws a resourceful light upon the structural, symbolic and functional qualities available in the text. Textual analysis helps to understand the language, symbols, pictures, and other information contained in the texts with a purpose to get knowledge about the ways people communicate through their language and their experiences. The analysis of a poem also involves in-depth analysis, placing great emphasis on its elements, e.g. rhyme and meter, and contribution of these elements to the meaning of a poem. It often explores the context in which a poem was written with the purpose of analyzing it in a new and unexpected way. This paper aims at the textual analysis of the "Full moon and Little Frieda" written by Ted Hughes. The analysis concludes that the poem is a vivid description of excitement that Hughes is experiencing while observing Frieda's sudden joy and amusement towards the moon which appears against the canvas of picturesque English countryside. The paper further concludes that Hughes suggests a relationship between humans and nature, and the enormous world which is formed by tiny objects and describes the natural world that he sees and what Frieda sees.
\end{abstract}

Keywords: Textual analysis, Full Moon and Little Frieda, Ted Hughes, Sylvia Plath, Text analysis

Description and interpretation of the characteristics of a text whether it is written in the form of a visual message is called textual analysis. Through textual analysis, the content, structure, and functions contained in a text are analyzed. As someone's language is an index of mind, examining the word choices helps to understand insights into the speaker or the writer's character. So textual analysis aims at understanding how people think and act, through studying their discourse patterns (Frey et al. 1999; Inayat 24). The textual analysis helps to understand the language, symbols, pictures, and other information contained in the texts with a purpose to get knowledge about the ways people communicate through their language and their experiences. This information can be sought from the apparent body of the text, starting from literal meaning and going through its subtext. All sorts of symbolism, assumptions, and values which are possibly revealed through a text is included in this type of analysis (Caulfield, 2019).

Different fields of text have different methods and aims of textual analysis. Usually, the aim is to establish a connection between the text and the context whether it is social, 
CODEN: LITIBR

Vol-2, Issue-1 ( $2^{\text {nd }}$ July, 2020)

Page No: 39-43

DOI: 10.47365/litinfinite.2.1.2020.39-43

\section{Section: Article}

political, cultural, or artistic. A text can be written, e.g. a book, an email, or a transcribed conversation or an object, meaningful and significant, and intended to be deeply interpreted such as a movie, an image, or even a place. As the methods of text analysis differ, the analysis of a poem focuses on the imagery, the narrative perspective, and the structure of the poem making the approach of the textual analysis creative and qualitative in this context. The analysis of a poem also involves in-depth analysis, placing great emphasis on its elements, e.g. rhyme and meter, and contribution of these elements to the meaning of a poem. It often explores the context in which a poem was written with the purpose of analyzing it in a new and unexpected way (Frey et al., 1999).

\section{Drifting into the realms of the non-industrial serenity of the country life in "Full Moon and Little Frieda:"}

"Full moon and Little Frieda" is probably written during Hughes' stay at Court Green (italicized) in Devon with Sylvia Plath. This was the year 1962 when Frieda was merely twoyear-old. They had the opportunity to observe Frieda's physical and mental growth. Observing their daughter possibly resulted in creative energy in them and writing of many poems consequently. It seems that this poem was written after Sylvia's death as it was published in Wodwo (italicized) in 1967. Hughes did not normally involve his family in his poetry, so in this regard, this is an important poem written by him. He only published his acclaimed Birthday Letters (italicized) in 1998, his death year that was written on memories of Sylvia Plath. In Sylvia Plath's poems, the moon was a significantly strong 'mother symbol.' Frieda as a motherless child is communicating with 'mother symbol' in this poem and the symbol is also communicating with her. Hughes seems to be lamenting that the mother cannot see her daughter communicating and establishing a relationship with the moon (Scutter, 2011).

This poem shows a once happy time in his life with Frieda and describes the moon rising, and looking down everything, especially Frieda and she looking at the moon with wonder. The poem shows the beauty of nature and suggests that this enormous world is formed from many intricate parts. The poem is a vivid description of excitement that Hughes is experiencing while observing Frieda's sudden joy and amusement towards the moon which appears on the picturesque countryside canvas of England. It is the evening time and the cows are returning home. The countryside is about to be covered by the evening dew and the first star of the evening is about to appear. Frieda, suddenly, seeing the full moon, exclaims "moon!" in childish joy (Gilbert, 2012; Caulfield, 2019).

The first stanza line 'Cool small evening shrunk to a dog bark and the clank' suggests a sense of touch connected to a sense of hearing. 'Shrunk' - evening is getting darker and this shows that perhaps there is the suggestion of having to rely on other senses 'dog bark and the clank of a bucket' - introduces one of the poem's main themes, which is the idea of humanity and its relationship with mother nature (Caulfield, 2019).

The second stanza is an appeal to the hearing sense of the reader. Frieda is enchanted by the sounds around her - a sense of wonder and amazement. It represents the idea that nature is made up of small things to form something beautiful. 'Dew's touch' represents 
CODEN: LITIBR

Vol-2, Issue-1 ( $2^{\text {nd }}$ July, 2020)

Page No: 39-43

DOI: 10.47365/litinfinite.2.1.2020.39-43

Section: Article

something pure, so it suggests that Frieda is pure. It may also suggest the life's cycle as the dew's touch is the start of the day. 'Pale' suggests milk that can appeal white, maybe Frieda who is pure and innocent. If the sky is reflected in milk, it will seem really different from normal. This means that the poet is suggesting that we should look at things differently.

The last two lines state that the moon is looking down from the sky like an artist. Stepping back and amazed as if he is admiring a painting just completed. The poet has also created a beautiful painting with his words describing the beautiful English countryside. Likewise, the moon with its beautiful moonlight has painted a picture in which the central attraction is Frieda (Scutter, 2011).

The poem depicts a typical English countryside scene with cows moving at dusk. Through father-daughter intimacy, the reader comes to know the intimacy of nature and humanity. This intimacy is however deeply integrated with an element of mystery and reciprocity because Frieda as a child is triumphant in understanding the identity of an object of nature, and nature recognizes something in humanity. This imagery makes the poem going beyond its geography, without disturbing the previous impression it has left on the reader. The relationship of art and the artist is understood and the relationship of the artist with the audience is also comprehendible by a simple phrase, a glance, or a rush. These relationships are the mirrors, held up against nature which makes it a 'Full' poem knowing the value of "Little" things. In this way, a true but unearthly moment is withdrawn from history (Gilbert, 2012).

The evening portrayed in the poem is not an unusual evening as evenings are usually the cooler part of the day. The poet calls it cool (italicized). When he says that the evening is small (italicized) perhaps it means that it is also insignificant with respect to what is going on. Then the day is shrunk, (italicized) because the light or the earth may be shrinking because of each other. In fact, there is nothing visual because the evening is reduced and limited to fewer sounds and noises. However, these are strong enough sounds and might be given attention. The presence of Frieda is added to the unseen bucket and dog and she is listening to these two sounds. Small (italicized) evening and little Frieda are blended together because the evening has become small for the little child (Scutter, 2011). The usage of "you" as a pronoun may add the audience to the scene also (Frey et al., 1999).

Hughes creates a mysterious yet calm atmosphere by raising the excitement of the reader line by line. It seems that after hearing the dog and the bucket, Frieda is tense and on guard for something to happen which Hughes intuitively knows. He keeps this suspense by continuing to describe the sounds in a soundless night. The bucket is clanking under a tap and the full pail is lifted with the care that no water is spilled. Frieda is listening to these sounds of the dusk. This may be a mirror for Frieda but not a mirror in the dark. It will actually become a mirror when the first star of the evening will give it its light because the water is tempted to see the star itself. The water in the bucket is related to a mirror in the sense of reflecting the stars in the sky (Gilbert, 2012). 
The image of the cows creates the rural setting in the poem through the words "going home" "looping the hedges" or "warm wreaths of breath." The alliteration in this line creates a soft, warm tone. The cows, because of their color, are related to "Dark River of blood" and there is a pessimistic tone of death. The boulders may represent the difficulties in life and "balancing unspilled milk" may be the struggle to survive, making a direct connection with Hughes' experiences. When the line about cows that are sending their warm breath into the hedges is read, the reader gets an idea about the height of the hedge. Hughes has been viewing the cows and Frieda's exclamation, but Frieda is only viewing and excited about what she has discovered, something that she can name. The moon has suddenly appeared from the cloud giving subtle paint to the countryside. The moon also seems quite amazed at discovering the little fascinated Frieda. The line, 'Moon!' you cry suddenly, 'Moon! Moon!' is perhaps the climax of this poem. In this way, this magical moment is also pregnant with suspense.

Frieda as a little child, when she sees the Moon for the first time, gives such reaction while the Moon has been personified as an artist gazing at his artwork symbolizing Hughes as a father observing his child's growing up. The Moon is the center of this moment. At his moment, the moon may also symbolize the mother as the creator of her daughter.

Little moments in life like a dog bark, clank of a bucket, or a child's seeing something in nature for the first time, are important. In this way, it is a 'Full' poem depicting the value of "Little" things of life. The hyphen and stanza break before the line "And you listening." The brevity found in it in contrast to the first line creates a picture that shows Hughes' love for his daughter. The pronoun 'you' shows that the focus of Frieda's fascination is on the insignificant noises of the countryside. There is a sequence found in the closely related images because Hughes notices a "spider's web" and a "pail" developing a setting and appearing contradictorily. The fragility of the web is contradictory to the heavy industrialism of the pail, yet they are closely linked through the words "tense" and "still." Moreover, both images are closely associated with water through the words "dew" and the "brimming." Further, both wait for quiet, yet beautiful, miracles of nature. "Touch" maybe the miracles of nature, maybe the "touch" of the first dew, or the reflected "tremor" of a star which makes the surface of the water a "mirror. A lively world is created, therefore, because this frequent personification which is linked by subtly distant alliteration of 't,' may also represent Frieda herself as metaphors. The fragility of the web is like Frieda's being "little," and waiting for the appearing of the moon as the web waits for the dew's touch (Gilbert, 2012).

A huge thematic shift is observed in the shift from second to the third stanza of the poem. This shift is from the theme of stillness to the theme of movement, from innocence to the experience, and from the beauty of life to the terror of death. There is a contrast between the relatively short lines and the sudden length of the first line of stanza two which creates a picture of an increase in pace and a resuming of time. The breaks in the lines of the first stanza promote stillness, pauses, contemplation, and expectation. Suddenly, cows that portray a threatening image of the "dark river of blood" create a continual flow. Their breath imagined as "wreaths" contributes to a funereal image. There is a thematic contrast between many things opposite in nature and characteristics, such as the innocence and the experience, 
Hugh as a father and Frieda as a little daughter. The world is differently perceived by Hughes as an adult from the perception of the world by Frieda. Hughes is unable to perceive the innocent beauty of the elements of nature i.e. the stars and the dew. He cannot enjoy the sound of their words like his daughter who exclaims "moon" a further three times. She cannot imagine the slaughter of cattle or the spilling of milk. Hughes is establishing a connection between earth and space through writing that the water in the pail can "tempt the first star to a tremor," although the reader knows that it is only the shaking reflection of the star. Frieda amazed at the moon, and the moon 'gazing amazed' back at Frieda also establishes the connection between earth and space. The moon is personified as an artist through the verb 'gazing.' It implies that this artist cannot take away his eyes off his fabulous creation (Gilbert, 2012).

The textual analysis of a poem usually focused on its imagery and narrative perspective. It further explains the structure of the poem making its approach creative and qualitative in nature. It involves an in-depth analysis of texts in which emphasis remains on elements of a poem such as its rhyme and meter. "Full Moon and Little Frieda" shows a once happy time in Ted Hughes' life with Frieda and describes her recognizing of the moon with wonder. Textual analysis of the poem shows the beauty of nature and suggests that this enormous world is formed from many intricate parts. It is a vivid description of excitement that Hughes is experiencing while observing Frieda's sudden joy and amusement towards the moon which appears against the canvas of picturesque English countryside. Hughes suggests a relationship between humans and nature, and the enormous world which is formed by tiny objects and describes the natural world that he sees and what Frieda sees.

\section{Works Cited}

i. $\quad$ Amir, Shamaila. "Discourse Analysis of Sindhi Folk Music: 'Tiri Pawanda' by Sheikh Ayaz." Electronic Research Journal of Literature 1 (2019): 9-12. Print.

ii. Amir, Shamaila. "Local Life in the Poetry of Naomi Shihab Nye: An Analysis of 'Making a Fist'." SSRN Electronic Journal (2020): n. pag. Print.

iii. Amir, Shamaila. "Text Analysis of Role of Satan in 'The Tragical History of Life and Death of Dr Faustus' by Christopher Marlow and Muslims' Perception of Satan in Pakistani Society." SSRN Electronic Journal 1.1 (2019): 92-95. Print.

iv. Dar, Firdous A. "Literature and its Impact on Women Empowerment: An Assessment." Electronic Research Journal of Social Sciences and Humanities 2.1 (2020): 92-95. Print.

v. Frey, Lawrence R., Carl H. Botan, and Gary L. Kreps. Investigating Communication: An Introduction to Research Methods. 2nd ed. New York: Pearson College Division, 2000. Print.

vi. $\quad$ "Full Moon And Little Frieda Analysis." ENotes. N.p., n.d. Web. 2 June 2020.

vii. $\quad$ Gilbert, Liam. "Space of Liam: Full Moon and Little Frieda - Analysis." Space of Liam. N.p., n.d. Web. 4 May 2020. <http://spaceofliam.blogspot.com/2012/02/full-moon-and-little-friedaanalysis.html?showComment=1334557983277>.

viii. $\quad$ Inayat, Muqaddas. "Notes on the English Character by EM Forster: A Critical Perspective." Electronic Research Journal of Social Sciences and Humanities 1.2 (2019): 21-27. Print.

ix. $\quad$ Razzak, Abdul. "Description of Utopia in Marshall Brain's Manna: An Analysis." Electronic Research Journal of Social Sciences and Humanities 1.1 (2019): 16-22. Print. 